\title{
Czynniki kształtujące intencje i zachowania przedsiębiorcze Ukraińców
}

\section{Factors Shaping the Entrepreneurial Intentions and Behaviours of Ukrainians}

Streszczenie: W literaturze przedmiotu relatywnie dużo jest opracowań na temat intencji i zachowań przedsiębiorczych oraz charakterystyk wybranych czynników indywidualnych, a zwłaszcza postaw przedsiębiorczych. Stosunkowo mało miejsca natomiast poświęca się na analizę wszystkich czynników indywidualnych, które pozostają ze sobą w interakcji. Chodzi o wzajemne oddziaływanie na siebie subiektywnych norm, postrzeganej kontroli zachowania oraz postaw przedsiębiorczych. W teorii planowanego zachowania I. Ajzena (1991) stanowią one bazę, a może również granicę intencji przedsiębiorczych, przy czym pozostają jednocześnie pod wpływem uwarunkowań wewnętrznych i zewnętrznych procesu przedsiębiorczego, których zasadnicze zróżnicowanie dotyczy krajowych układów przestrzennych, ale czasem także regionalnych i lokalnych. W świetle powyższego celem artykułu jest identyfikacja czynników indywidualnych kształtujących intencje i zachowania przedsiębiorcze Ukraińców. Za szczególnie istotną przyjęto próbę eksplikacji postaw przedsiębiorczych w kontekście obowiązujących norm społeczno-kulturowych w Ukrainie na tle wybranych państw europejskich. Prezentowane wyniki w różnych układach przestrzennych odzwierciedlają trudną i złożoną sytuację społeczno-gospodarczą i polityczną panującą w Ukrainie, co można tłumaczyć szeregiem czynników egzo- i endogenicznych, w tym silnym zróżnicowaniem kulturowym kraju, kondycją ekonomiczną ukraińskich rodzin oraz stosunkiem obywateli do procesu przedsiębiorczego.

\begin{abstract}
In the literature there is a relatively high number of studies on the entrepreneurial intentions and behaviours and characteristics of the selected individual factors, especially entrepreneurial attitudes. However, relatively little time is devoted to the analysis of all individual factors that interact with each other. It is about the interaction of subjective norms, perceived control of behaviour and entrepreneurial attitudes. In I. Ajzen's Theory of Planned Behaviour (1991) they constitute the base, and maybe also the limit of entrepreneurial intentions, while being under the influence of internal and external conditions of the entrepreneurial process, the fundamental diversity of which applies to national spatial systems, but sometimes also to regional and local ones. The purpose of the study is to identify individual factors shaping the intentions and entrepreneurial behaviours of Ukrainians. An attempt to clarify entrepreneurial attitudes in the context of existing socio-cultural norms in Ukraine against
\end{abstract}


the background of selected European countries was considered to be particularly important. The presented results in various spatial systems reflect the difficult and complex socio-economic and political situation in Ukraine, which can be explained by a number of exo- and endogenous factors, including the strong cultural diversity of the country, the economic condition of Ukrainian families and the attitude of citizens towards the entrepreneurial process.

Słowa kluczowe: intencje i zachowania przedsiębiorcze; normy społeczno-kulturowe; proces przedsiębiorczy; Ukraina

Keywords: entrepreneurial intentions and behaviours; entrepreneurial process; socio-cultural norms; Ukraine

Otrzymano: 1 listopada 2019

Received: 1 November 2019

Zaakceptowano: 19 kwietnia 2020

Accepted: 19 April 2020

\section{Sugerowana cytacja/Suggested citation:}

Czaplińska, A. (2020). Czynniki kształtujące intencje i zachowania przedsiębiorcze Ukraińców. Przedsiębiorczość - Edukacja [Entrepreneurship - Education], 16(1), 212-224. doi: 10.24917/ 20833296.161.17

\section{Wstęp}

Wychodząc z założenia, że przedsiębiorczość stanowi podstawowy warunek rozwojowy, należy ją także widzieć jako proces, w którym czynniki indywidualne, takie jak postawy przedsiębiorcze, subiektywne normy oraz postrzegana kontrola zachowania, pozostają ze sobą w stałej interakcji i wpływają na intencje przedsiębiorcze, a te - na zachowania przedsiębiorcze (m.in. Ajzen, 1985, 1991; Crisp, Turner, 2009; Kurczewska, 2010; Łuczka, Rembiasz, 2016; Pawlak, 2018; Rachwał, Wach, 2016; Sadowska, 2017; Zbierowski, 2014).

Peter Nijkamp (2003) podkreśla, że literatura nie wskazuje jednoznacznych czynników determinujących przedsiębiorcze zachowania jednostki. Z kolei D. Piróg (2014), która badała determinanty warunkujące powstanie i rozwój przedsiębiorczości, zwraca uwagę na uwarunkowania zewnętrzne (ekonomiczne i społeczne), które niejako otaczają człowieka, oraz uwarunkowania wewnętrzne, rozumiane jako indywidualne cechy jednostki, jej wykształcenie i doświadczenie. Podział ten ma wyraźnie osobowy charakter (tzw. czynnik ludzki) i chociaż nie podlega krytyce jako takiej, to może mieć subiektywny charakter. Odmiennie do podziału uwarunkowań podchodzą I. Kavetskyy oraz P. Czapliński (2019), którzy za kryterium podziału uwarunkowań przyjęli kryterium przestrzenne. Uznali oni, że uwarunkowania wewnętrzne to wszystkie te czynniki, które oddziałują na cały proces przedsiębiorczy, na wszystkie jego elementy w skali lokalnej i regionalnej, ale przede wszystkim krajowej. Natomiast uwarunkowania zewnętrzne to te, które oddziałują na ten sam, cały proces przedsiębiorczy, ale ich źródło pochodzi ze skali globalnej, a przynajmniej międzynarodowej. Taki podział, przy jasno ustalonych granicach wydaje się być obiektywny. Warto jednak wskazać na nierozwiązany problem zestawu czynników w obu grupach uwarunkowań, siły ich działania oraz zachowań w czasie (np. czy jest to czynnik epizodyczny, okresowy, stały). Zaproponowany podział zwraca jednak uwagę na istotność skali przestrzennej w rozważaniach nad procesem przedsiębiorczym, który być może będzie różny nie ze względu na indywidualne cechy 
i doświadczenie jednostki, a nawet zachodzące procesy społeczno-gospodarcze w otoczeniu, ale na różnorodność przestrzeni. Nie ma bowiem dwóch takich samych miejsc dla rozwoju przedsiębiorczości.

Potwierdza to szereg wcześniejszych badań (Grzegorzewska-Mischka, 2010; Moczydłowska, Pacewicz, 2007; Safin, 2002), w których przedsiębiorczość jest postrzegana jako wynik zderzenia różnorodnych czynników, wzajemnie się przenikających, które mogą zarówno pobudzać, jak i ograniczać lub hamować jej rozwój. Rozwój przedsiębiorczości w określonym miejscu i określonym czasie może nastąpić jedynie na skutek sprzyjającego wpływu określonego, choć nie stałego, zestawu czynników. Nawet osoba silnie zmotywowana do działania oraz posiadająca niezbędną wiedzę do tego, by stać się przedsiębiorcą, nic nie osiągnie, jeżeli miejsce, w którym funkcjonuje, jest niesprzyjające.

W świetle powyższych ustaleń teoretycznych celem opracowania jest identyfikacja czynników kształtujących intencje i zachowania przedsiębiorcze Ukraińców w ostatnich kilku latach, a pośrednio - charakterystyka postaw przedsiębiorczych i poczucia własnej skuteczności w interakcji z panującymi w Ukrainie normami społeczno-kulturowymi na tle wybranych państw europejskich. Podjęty cel wpisuje się również w szerszą dyskusję na temat wpływu środowiska na funkcjonowanie jednostki (tu: obywatela), zwłaszcza na jego cechy osobowościowe i sposób myślenia. Wyniki przeprowadzonych badań stanowią także drobną przesłankę do dyskusji nad modelem zaproponowanym przez Ajzena (1985, 1991 i in.) w części poświęconej wpływom czynników zewnętrznych na proces przedsiębiorczy.

\section{Założenia metodyczne badań}

Głównym źródłem informacji były ogólnodostępne raporty AGER (Amway Global Entrepreneurship Raport), opublikowane w latach 2015, 2016 i 2018. Głównym wykonawcą raportów był Instytut GfK (Gesellschaft für Konsumforschung) z Norymbergii, który pod patronatem Uniwersytetu Technicznego w Monachium wykonał badania dla działającej w systemie network marketing Amway Corporation. Główną część raportów stanowią wyniki badań ankietowych przeprowadzonych w kilkudziesięciu krajach świata na próbach reprezentatywnych z zachowaniem podstawowych ustaleń metodologicznych.

Zgodnie z przyjętym celem badań, z obszernych raportów AGER wybrano dane dotyczące Ukrainy, koncentrując się na wszystkich czynnikach indywidualnych determinujących intencje przedsiębiorcze. Ich agregacją jest prezentowany w raportach indeks, tzw. indeks ducha przedsiębiorczości (AESI: Amway Enterprenerial Spirit Indeks), który jest średnią trzech składowych:

1. postaw przedsiębiorczych, których emanacją jest stwierdzenie: Uważam, że założenie firmy to moja szansa zawodowa;

2. subiektywnych norm sprowadzających się do stwierdzenia: Rodzina i znajomi nigdy nie zniechęcają mnie do podjęcia własnej działalności gospodarczej;

3. postrzeganej kontroli zachowania utożsamianej z opinią: posiadam niezbędne umiejętności i zasoby dla podjęcia własnej działalności gospodarczej.

W opracowaniu wykorzystano również wyniki własnych badań dotyczących intencji przedsiębiorczych młodych Ukraińców z Bukowiny. Badania przeprowadzono w przekrojowym badaniu bezpośrednim w maju 2019 r. Liczebność próby wniosła 132 osoby w wieku 17-24 lata. Dobór jednostek próby miał charakter nielosowy, niemniej na podstawie 
wiedzy o parametrach populacji regionu z roku 2019 ma on odbicie w strukturze płci, wykształcenia oraz statusie społeczno-zawodowym badanej warstwy (Sarchynska, 2019). Można zatem uznać, że ma on znamiona doboru kwotowego.

Wyniki badań

Poddając szczegółowej analizie czynniki indywidualne zawarte w indeksie AESI, należy stwierdzić, że jego wielkości dla Ukrainy wyrażone we wszystkich trzech składowych są znacznie niższe od średniej dla Unii Europejskiej, w tym wybranych krajów sąsiadujących, w tym także Polski. Szczególnie duża różnica dotyczy postrzeganej kontroli zachowania (11 p.p. w stosunku do Polski i aż 23 p.p. w przypadku UE), co wprost przekłada się na sygnalizowane przez Ukraińców braki dotyczące posiadania kompetencji w zakresie prowadzenia działalności gospodarczej. W badaniach uzupełniających wyjaśniono, że braki te dotyczą najprostszego ujęcia kompetencji, tj. ujęcia instruktażowego, które w zasadzie odnosi się tylko do wiedzy. Bardziej zaawansowane ujęcia, np. triadowe lub kreatywno-predykcyjne, są w zasadzie nieobecne w świadomości wielu respondentów. Wydaje się, że krytyczna samoocena własnych kompetencji, w tym sama świadomość posiadanych braków, niewątpliwie wpływa na postawy przedsiębiorcze, których ocena w Ukrainie jest również zła. Na tym tle wsparcie rodziny i przyjaciół do podjęcia własnego biznesu wypada nieznacznie lepiej. Warto jednak dodać, że zwykle dotyczy ono przyjęcia do wiadomości takiej informacji, ewentualnie wsparcia emocjonalnego, a nie merytorycznego (rycina 1).

Rycina 1. Indeks AESI dla Ukrainy na tle wybranych państw europejskich*

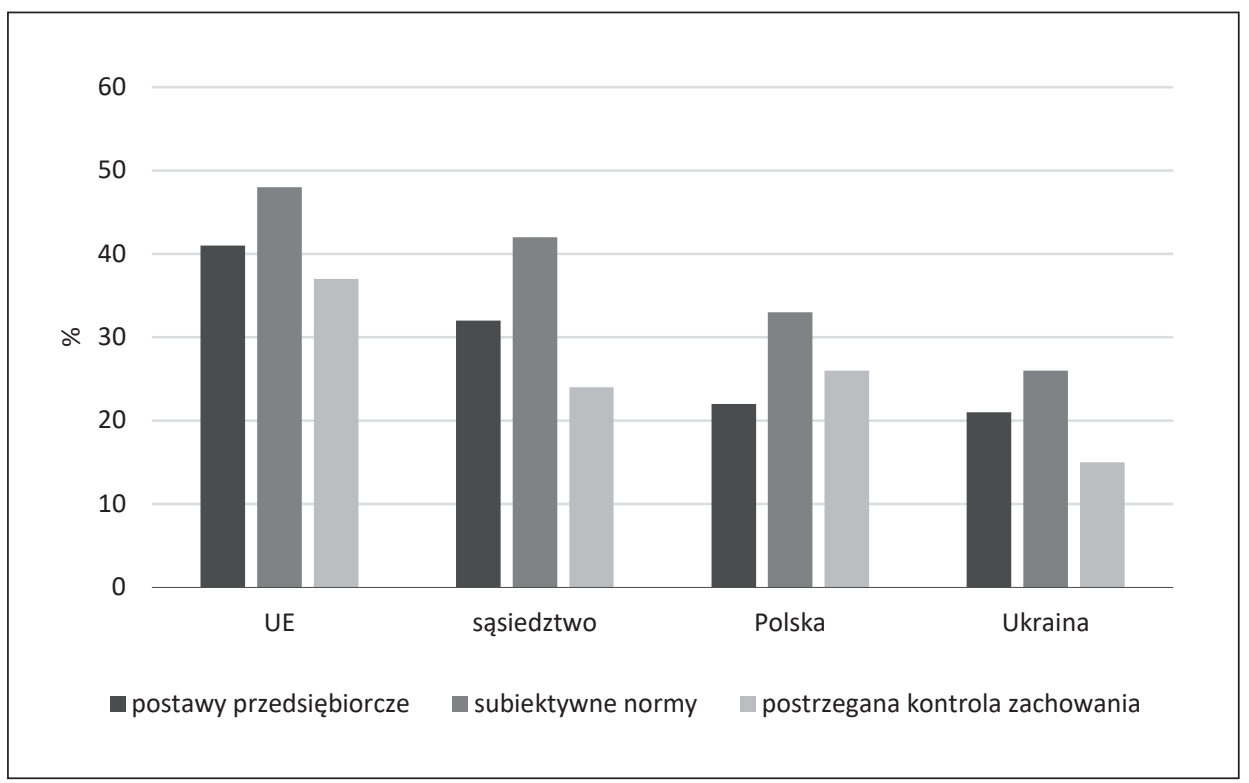

* UE - wybranych 25 krajów Unii Europejskiej; sąsiedztwo - wybrane kraje sąsiadujące z Ukrainą: Polska, Rosja, Rumunia, Słowacja, Węgry

Źródło: opracowanie własne na podstawie raportu AGER 2018 
Za szczególnie niebezpieczne należy uznać to, że w latach 2015-2018 wszystkie wielkości składowych AESI i tak relatywnie niskie uległy dalszej redukcji. Przy czym największe spadki odnotowano w postawach przedsiębiorczych (-21 p.p.), następnie w subiektywnych normach ( -17 p.p.), a relatywnie najmniejsze ujemne zmiany zaszły w kontroli zachowań (-13 p.p.). Nie oznacza to jednak lepszej średniookresowej pozycji tej składowej. Jej wielkość w roku bazowym (2015 r.) była znacząco niższa od pozostałych, stąd dalszy spadek nie był już tak gwałtowny, chociaż był widoczny zwłaszcza w zestawieniu z danymi z lat 2016 i 2018. To wyraźne załamanie i tak już niekorzystnego trendu po $2016 \mathrm{r}$. dotyczy zresztą wszystkich składowych i jest konsekwencją gwałtownie pogarszającej się ogólnej sytuacji makroekonomicznej Ukrainy, nastrojów i aktywności społecznej oraz sytuacji politycznej. Niepewność społeczno-ekonomiczna spowodowała, że wielu Ukraińców wyjechało w celach zarobkowych za granicę, a pozostali zaczęli często podejmować doraźne, czasem gwałtowne, decyzje dotyczące aktywności gospodarczej, nie dokonując głębszej refleksji nad czynnikami indywidualnymi stymulującymi intencje i zachowania przedsiębiorcze. Można nawet przyjąć, że Ukraińcy zostali pozostawieni sami sobie. To stąd tak niskie oceny składowych indeksu (rycina 2).

Rozkład przestrzenny indeksu AESI dla Ukrainy w 2018 r. wskazuje na istotne różnice międzyregionalne, które mają najprawdopodobniej podłoże historyczno-kulturowe. Najkorzystniejsza sytuacja występuje w zachodniej części kraju, gdzie średnia wartość składowych indeksu wyniosła 37\%, dla części centralnej 28\%, wschodniej - 27\%, a dla południa - zaledwie 16\%. Miasto stołeczne Kijów nie jest tutaj wyjątkiem (średnia 30\%), co dziwi ze względu na uprzywilejowaną pozycję miasta w strukturze osadniczej, jego funkcje centralne oraz ułatwienia w dostępie do otoczenia biznesu. Potwierdza się w ten sposób stary zachodnioukraiński stereotyp o tym, że na zachodzie Ukrainy mieszkaja osoby zaradne, określane jako „gazdy”, a na wschodzie kraju społeczności lokalne, które cechuje bierność, nazywane w wolnym tłumaczeniu „nygusami”.

Rycina 2. Indeks AESI dla Ukrainy w latach 2015, 2016, 2018

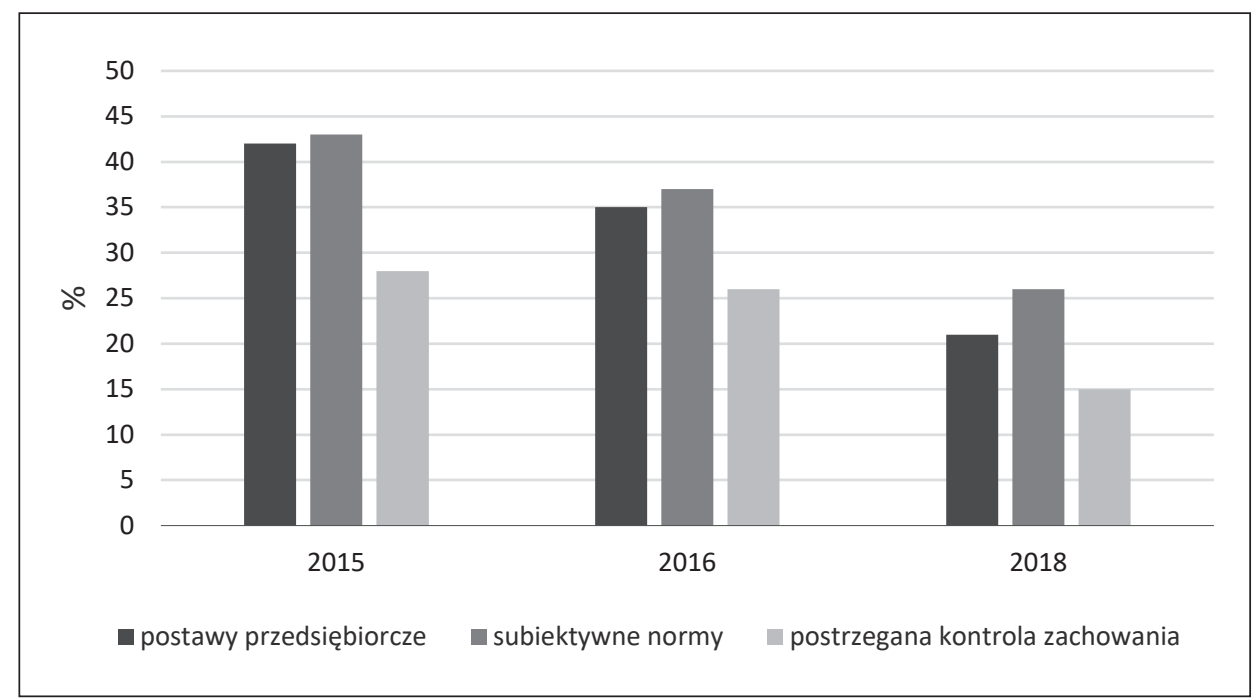

Źródło: opracowanie własne na podstawie raportu AGER 2015, 2016, 2018 
W strukturze wiekowej badanej próby Ukraińców z 2018 r. widoczna jest malejąca zależność pomiędzy „duchem przedsiębiorczości” a wiekiem. Można nawet przyjąć założenie, że im badany jest starszy, tym bardziej niepewny w intencjach i zachowaniach przedsiębiorczych. Z jednej strony wydaje się to oczywiste, np. jeżeli uwzględni się stosunek do działań długoterminowych, z drugiej jednak strony nie koryguje takiej postawy rosnące doświadczenie życiowe i zawodowe. Gwałtowny spadek zainteresowania przedsiębiorczością widoczny jest zwłaszcza w grupie wiekowej 50 i więcej lat, co może wyjaśniać specyfika pokoleniowa i związane z nią inne uwarunkowania krajowe i międzynarodowe, które odcisnęły swoje piętno na postawach społecznych, w tym na stosunku do przedsiębiorczości.

W rozwoju przedsiębiorczości uwarunkowania krajowe wydają się szczególnie istotne, ponieważ dają pewną ramę prawno-administracyjną i społeczno-kulturową intencji i zachowań przedsiębiorczych. Stąd też przy identyfikacji postaw przedsiębiorczych Ukraińców zasadnym wydało się uwzględnienie pytania o ocenę krajowego systemu podatkowego, prawnego, edukacyjnego, poziomu technologicznego i sytuacji społeczno-politycznej kraju. Na tle równocześnie badanych krajów europejskich Ukraina wypadła bardzo niekorzystnie, a różnica w sumie wymienionych składowych pomiędzy Ukrainą a Szwajcarią i Holandią (liderami rankingu) wyniosła ponad 70 p.p. Wpływ na uzyskany wynik miała słaba wiedza lub - co bardziej niepokojące - nieświadomość respondentów w sprawie niektórych mechanizmów funkcjonowania państwa, co samo w sobie nie sprzyja rozwojowi przedsiębiorczości. Potwierdzają to również badania uzupełniające, które skłaniają do refleksji nad rolą i znaczeniem czynnika kulturowego w interpretacji uzyskanych wyników, który to czynnik przejawia się w poziomie samokrytyki Ukraińców. Nie bez znaczenia pozostaje również poziom demokracji, który rzutuje na całą sytuację społeczno-gospodarczą kraju w perspektywie operacyjnej i strategicznej.

Zapewne dlatego odpowiedzi na kolejne pytanie, dotyczące szans na rozpoczęcie działalności gospodarczej w Ukrainie, są raczej pesymistyczne (rycina 3). Uwagę zawraca bardzo wysoki odsetek braku odpowiedzi (34\%), co najprawdopodobniej jest zabiegiem maskującym odpowiedź „nie”, oraz umiarkowany odsetek odpowiedzi "prawdopodobne”. Brak odpowiedzi, a de facto odpowiedzi na "nie” wynikają z diagnozy aktualnego stanu, który przeniesiony w przyszłość nie budzi nadziei, co znacząco upośledza procesy przedsiębiorcze oraz zniechęca do ich podejmowania zwłaszcza wchodzących na rynek pracy. Ponadto o ogólnym, powszechnym rozwoju przedsiębiorczości nie decydują liderzy (utożsamiani z sugerowaną odpowiedzią - „bardzo prawdopodobne”), a ich naśladowcy, czyli Ci, którzy prawdopodobnie rozpoczną działalność gospodarczą. W przypadku Polski jest to $41 \%$, średnia dla krajów sąsiadujących z Ukrainą wynosi $38 \%$, a w przypadku samej Ukrainy to $29 \%$. Za relatywnie niski należy także uznać odsetek odpowiedzi „bardzo prawdopodobne” (25\%), co poza czysto ilościową interpretacją pozwala założyć mniejszą presję na "bycie pierwszym” z wszystkimi tego konsekwencjami, np. w postaci działań innowacyjnych. W badaniach uzupełniających, potwierdzających ogólne wyniki raportów AGER, zauważono, że w najmłodszym pokoleniu dopiero wchodzącym na rynek pracy widoczny jest młodzieńczy optymizm, który w konfrontacji z krajowymi realiami życia gospodarczego może zostać szybko wyhamowany, co w konsekwencji może to doprowadzić do emigracji zarobkowej. Spośród ankietowanej młodzieży z Czerniowców 75\% planuje rozpoczęcie własnej działalności gospodarczej w różnej perspektywie czasowej, a tylko $25 \%$ nie planuje lub nie ma zdania na ten temat. 
Rycina 3. Ocena szans rozpoczęcia własnej działalności gospodarczej w perspektywie najbliższych 5 lat

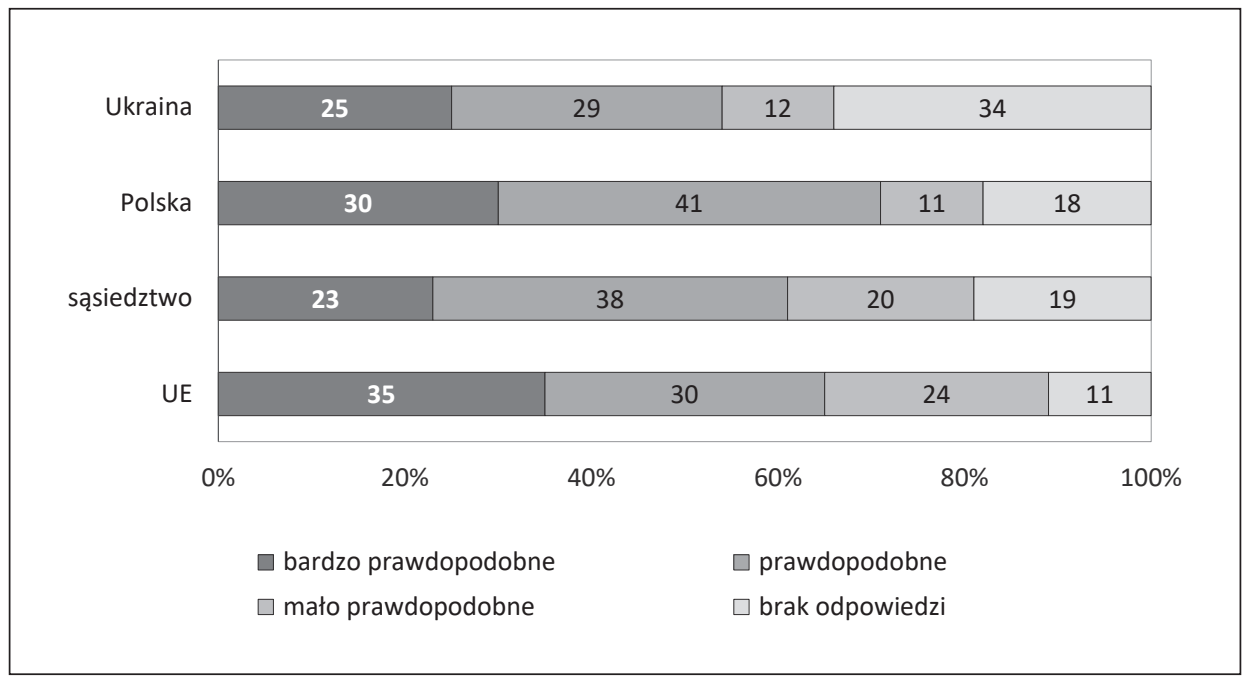

Źródło: opracowanie własne na podstawie raportu AGER 2016

Głównym i oczywistym powodem podejmowania działalności gospodarczej jest generowanie zysku w celu realizacji potrzeb własnych i potrzeb wynikających z sytuacji rodzinnej i społecznej przedsiębiorcy. Należy się spodziewać, że im większy niedobór w realizacji potrzeb tym większa presja w celu ich zaspokojenia. Innymi słowy, im społeczność uboższa, tym większa motywacja do pracy. Potwierdzają to wyniki uzyskane dla Ukrainy, które ilustrują poziom zamożności jej mieszkańców i tego konsekwencje (rycina 4). Ukraińcy, decydując się na własne źródło zarobkowania, traktują je głównie jako dodatkowe źródło dochodów w wymiarze czysto finansowym. Presja finansowa jest w Ukrainie tak duża, że podejmowane aktywności (czasem na granicy prawa) odbywają się kosztem relacji rodzinnych, czasu wolnego i potrzeby samorealizacji. Równocześnie dodatkowy zarobek pozwala zwykle na zaspokojenie głównie potrzeb fizjologicznych i w znacznie węższym zakresie jakościowym - potrzeby bezpieczeństwa. Ponadto obywatele Ukrainy nie widzą wyraźnych korzyści płynących z pracy na własny rachunek, co należy łączyć ze wspomnianą już zaszłością historyczną i kulturową oraz wcześniej wspomnianym poczuciem niepewności, zwłaszcza w średnim i starszym pokoleniu. Potwierdza to również poziom oceny własnych możliwości w zakresie zakładania i prowadzenia działalności gospodarczej (rycina 5). Uwagę zwraca bardzo niski poziom intencji przedsiębiorczych, w tym gotowości do poświęceń w zakresie czasu. Gotowość ta w Ukrainie jest pięciokrotnie mniejsza niż średnia dla państw UE i dwukrotnie mniejsza niż w Polsce, tymczasem optymizm i pracowitość to fundament osoby przedsiębiorczej. Podobne proporcje występują we wszystkich prezentowanych obszarach, również w tak elementarnym - nie tylko z punktu widzenia przedsiębiorczości - jak wsparcie rodziny i znajomych. Elementarnym, bowiem rodzina i znajomi to często pierwsi recenzenci, kibice, klienci, a przede wszystkim - współpracownicy i doradcy w prowadzeniu własnego biznesu. W ocenie własnych możliwości najistotniejszą pozostaje jednak bariera finansowa, która dotyka obywateli wszystkich państw, chociaż Ukrainę najbardziej. 
Rycina 4. Powody podjęcia działalności gospodarczej

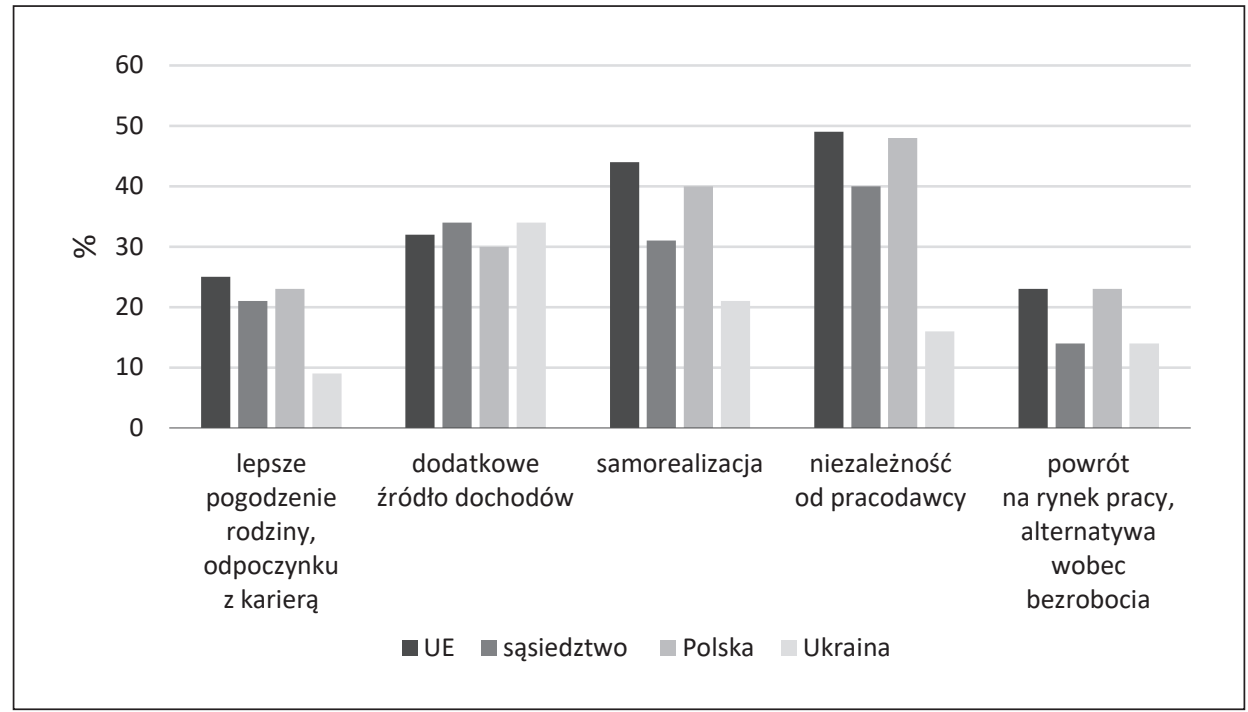

Źródło: opracowanie własne na podstawie raportu AGER 2016

Rycina 5. Ocena własnych możliwości w zakresie zakładania i prowadzenia działalności gospodarczej

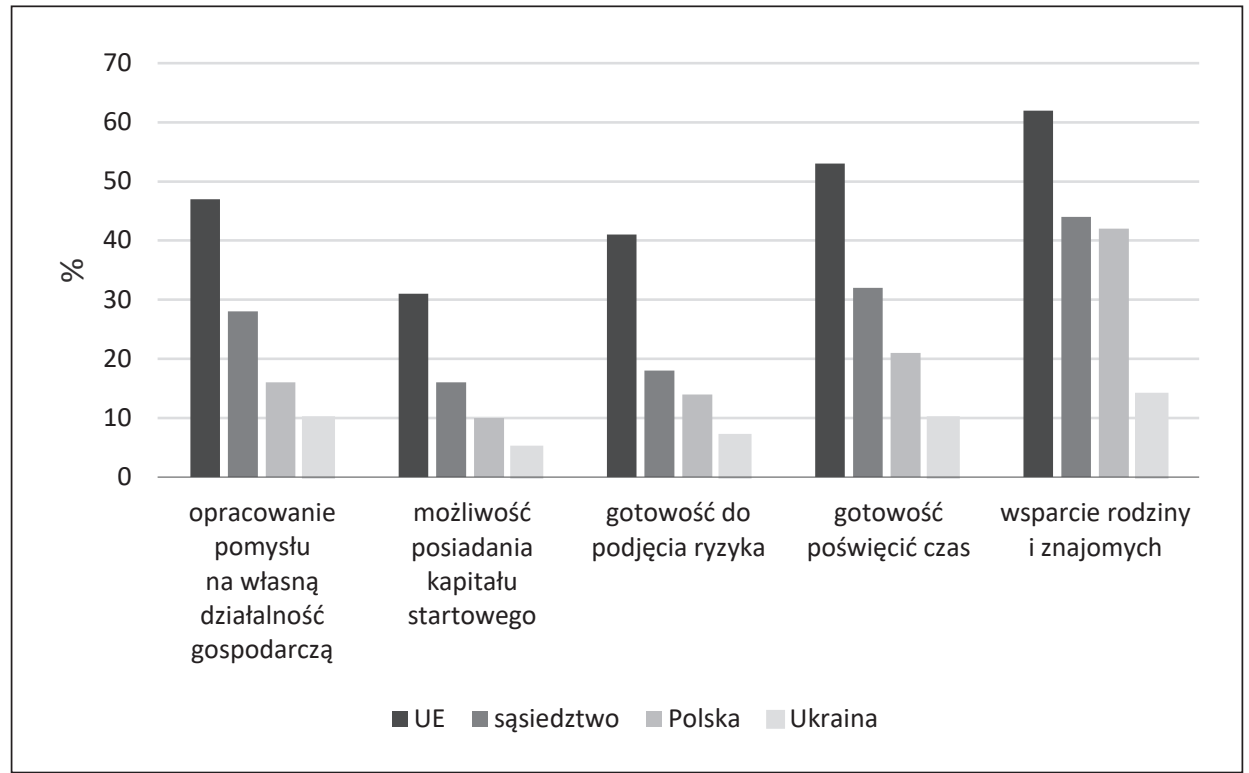

Źródło: opracowanie własne na podstawie raportu AGER 2018

Badania uzupełniające w Czerniowcach potwierdzają powyższą tezę o barierze finansowej, która w sposób szczególny dotyka osób młodych i staje się poważnym ograniczeniem, podobnie jak obawa, lęk w prowadzeniu biznesu, wynikający być może z braku wiedzy, oraz nadmierna biurokracja (rycina 6). 
Rycina 6. Czynniki zniechęcające do rozpoczęcia działalności gospodarczej na przykładzie młodzieży z Bukowiny (Ukraina)

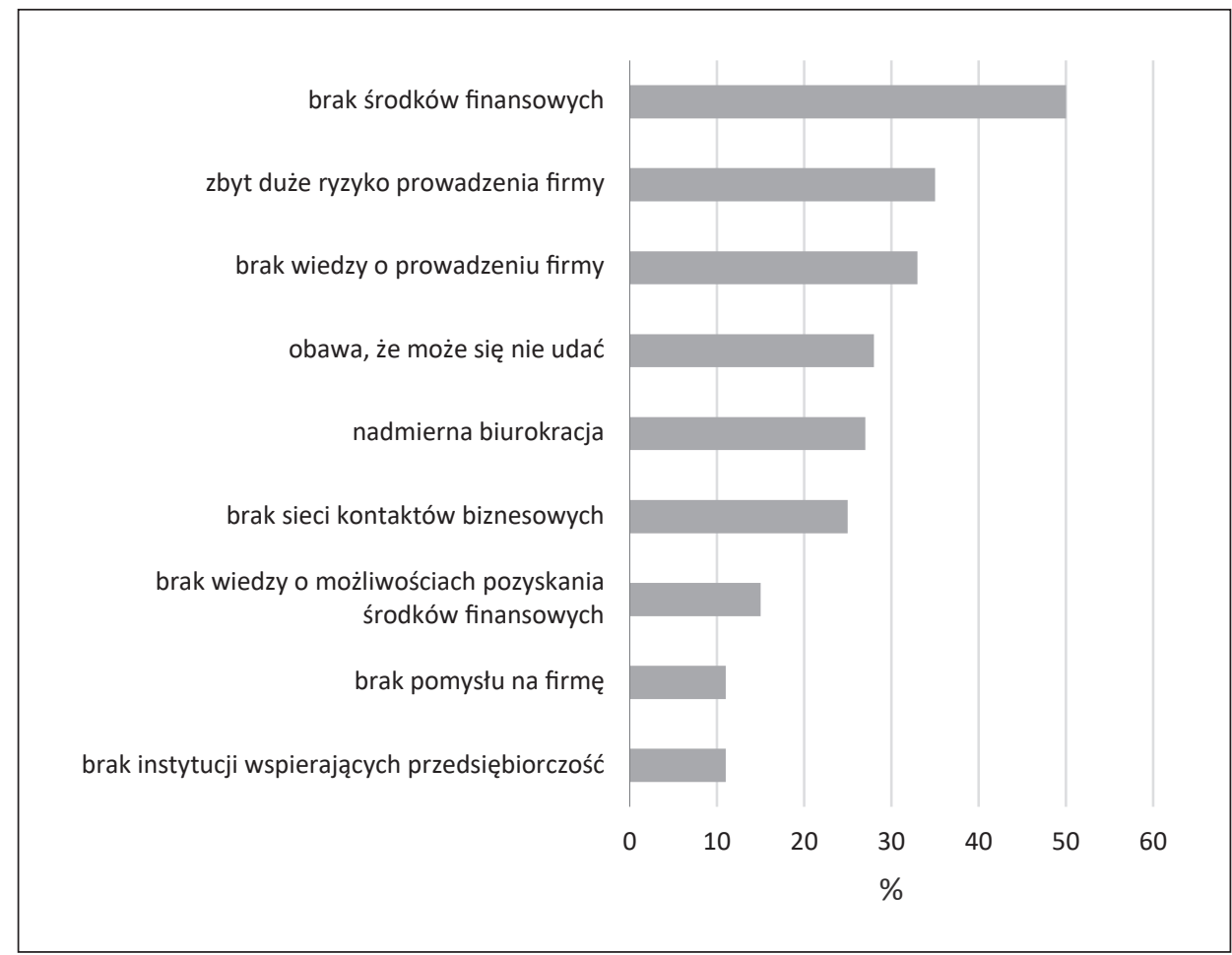

Źródło: opracowanie własne na podstawie przeprowadzonych badań terenowych w 2019 r.

Trudno jest określić, jakie cechy osobowości najlepiej sprawdzą się w określonym miejscu, czasie i stanowisku, niemniej jednak istnieje pewna grupa przymiotów, które mogą znacząco pomóc w procesie przedsiębiorczym. Z badań uzupełniających wynika, że cechy, które mają wspomóc proces przedsiębiorczy Ukraińców, choć pożądane, wydają się stereotypowe i mało aktualne (rycina 7). We współczesnej grze rynkowej, która prowadzona jest w szybkim tempie i w oparciu o coraz to nowsze przewagi konkurencyjne, pożądane są czasem wysoce specjalistyczna kreatywność oraz szybkość reagowania na sytuacje nietypowe. Te cechy znalazły się na liście, ale ich pozycja jest daleka od zadowalającej. Ponadto to właśnie kreatywność i łatwość w podejmowaniu inicjatywy oraz reakcja na zmiany to istota współczesnej przedsiębiorczości

Skoro największą barierą w aktywności przedsiębiorczej jest bariera finansowa, nie dziwią wyniki następnego zestawienia dotyczącego potrzeby wsparcia dla wszystkich uwzględnionych $\mathrm{w}$ badaniach państw, z wyjątkiem przypadku Ukrainy, gdzie odnotowano niskie oczekiwania przedsiębiorców dotyczące wsparcia ich działalności (rycina 8). Może to wynikać z braku świadomości lub wiedzy o takich możliwościach albo też z braku wiary w możliwości pozyskania środków. Szczególnie wyraźna różnica pomiędzy Ukrainą a pozostałymi państwami dotyczy poszukiwania środków na działalność i obsługę finansową firmy, a relatywnie mała - fachowości zatrudnianej kadry, co dobrze świadczy o ukraińskich zasobach pracy. 
Rycina 7. Cechy ułatwiające znalezienie i podjęcie pracy/rozpoczęcie własnej działalności gospodarczej na przykładzie młodzieży z Bukowiny (Ukraina)

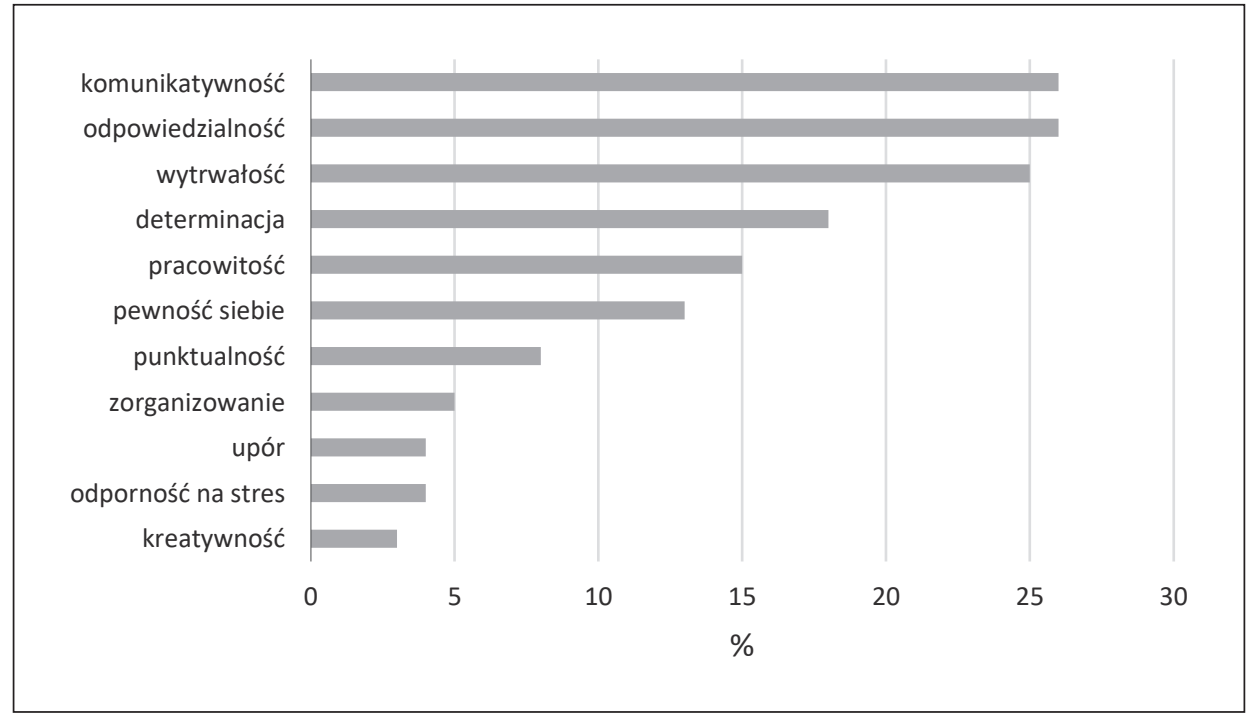

Źródło: opracowanie własne na podstawie przeprowadzonych badań terenowych w 2019 r.

Rycina 8. Potrzeba wsparcia w wybranych obszarach prowadzenia własnej działalności gospodarczej

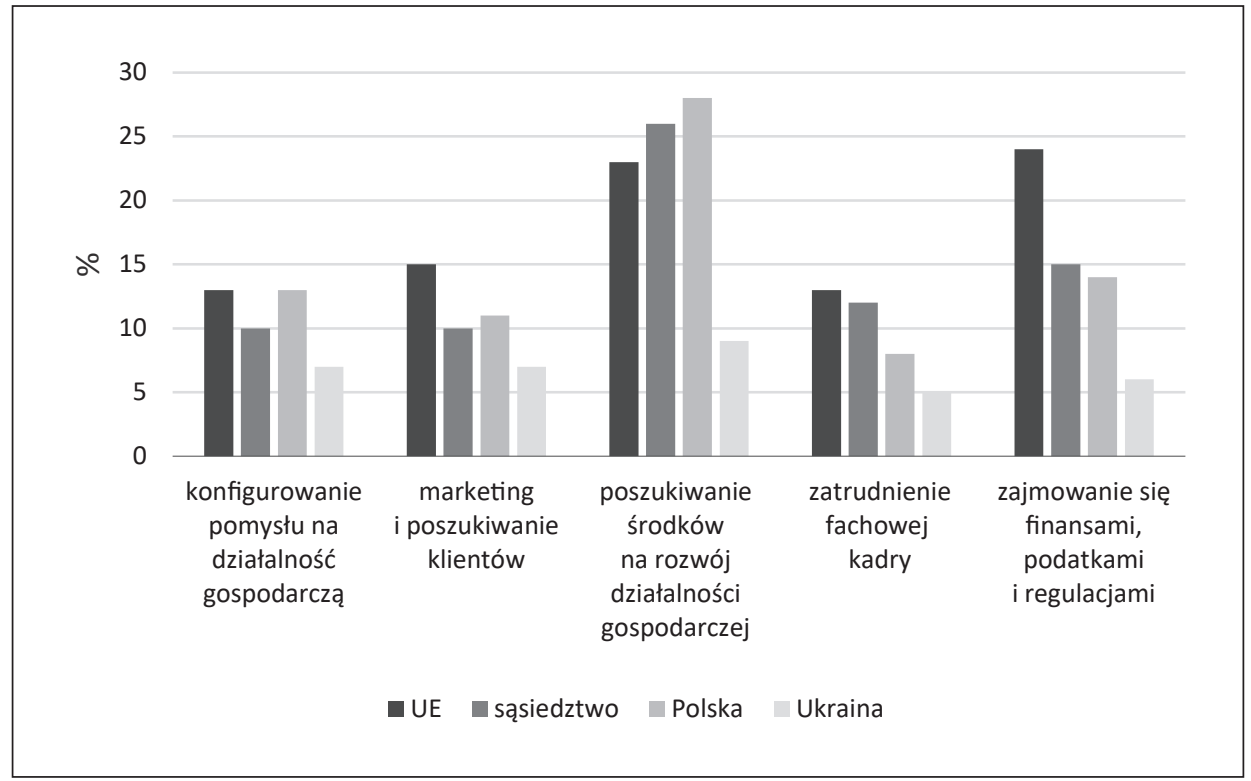

Źródło: opracowanie własne na podstawie raportu AGER 2018

Ostatnim wątkiem podjętym w badaniach była próba określenia charakterystycznych, jednak tylko deklarowanych cech działalności gospodarczej w Ukrainie na podstawie zakresu działalności (produkcja/usługi), formy obsługi (bezpośrednia/internetowa), miejsca 
działalności (miasto/wieś), organizacji działalności (indywidualna/zespołowa) oraz celu działalności (profit/non profit). Z danych prezentowanych w raportach AGER wynika, że istnieją duże różnice pomiędzy zestawem cech charakterystycznych dla poszczególnych krajów wynikające zapewne z różnych norm społecznych i kodów kulturowych, które determinują intencje i zachowania przedsiębiorcze. Najbardziej charakterystyczne cechy działalności gospodarczej w Ukrainie to:

- znaczne wyższy od pozostałych krajów udział usług w planowanej działalności (81\%),

- znacznie wyższy od pozostałych krajów udział wsi jako miejsca planowanej działalności (52\%),

- znacznie wyższy udział obsługi klientów przez internet (57\%),

- niższy od innych udział działalności indywidualnej (62\%),

- porównywalny ze średnią europejską odsetek organizacji non profit (45\%).

Wszystkie deklarowane cechy mogą wynikać z czynnika kosztowego, ale równocześnie mogą być potwierdzeniem stanu niepewności wśród realnych i potencjalnych przedsiębiorców. Nie bez znaczenia pozostaje również czynnik społeczno-kulturowy determinujący cechy osobowościowe i sposoby myślenia, w tym myślenia przedsiębiorczego. Zaobserwowane różnice nie mają charakteru oceniającego, a jedynie charakter poznawczy, co wydaje się istotne w dalszych rozważaniach na temat uwarunkowań zewnętrznych i wewnętrznych procesu przedsiębiorczego.

\section{Zakończenie}

Zaprezentowane wyniki badań dotyczące postaw przedsiębiorczych Ukraińców sensu largo każą zwrócić uwagę na człowieka jako kluczową siłę sprawczą w procesie przedsiębiorczym. Jego obecna postawa w Ukrainie wymaga pilnej, głębokiej i powszechnej interwencji w celu odbudowy fundamentalnych cech dla przedsiębiorczości, którymi są: pozytywne myślenie oraz pracowitość. Na tej podstawie należy realizować kolejne etapy inwestycji w człowieka przedsiębiorczego, uświadamiając i kształtując zasoby intelektualne i emocjonalne. Należy obudzić ducha przedsiębiorczości w Ukraińcach, ponieważ przedsiębiorczość cechuje wszystkich ludzi, a jedynym pytaniem jest to, czy z tego skorzystają, czy nie.

Równie ważne wydaje się dostrzeganie przestrzeni w procesie przedsiębiorczym. Przedsiębiorczość odbywa się przecież w sformalizowanych układach przestrzennych, z których układ krajowy najbardziej determinuje wszystkie przejawy aktywności przedsiębiorczej. W tym kontekście należy zwrócić uwagę na Ukrainę jako miejsce podejmowania tych aktywności. Jej obecna, złożona sytuacja społeczno-ekonomiczna w wielu przypadkach jest destymulantą dla przedsiębiorczości, co potwierdzają badania. Wydaje się jednak, że mamy tu do czynienia z przyczynowością kulistą, czyli nierozwiązywalnym sporem o to, co zależy od czego w relacji miejsce-człowiek. Nie wdając się w głębszą analizę i być może spór pomiędzy zwolennikami a przeciwnikami determinizmu geograficznego, należy wypracować nową strategię rozwoju przedsiębiorczości dla Ukrainy, wydaje się bowiem, że obecna jest ona domeną bardzo wąskiej grupy, tymczasem świadomość, wiedza i umiejętności na temat przedsiębiorczości winny być powszechne. Dlatego też pojawia się pilny postulat, aby edukacja w zakresie przedsiębiorczości wróciła do systemu edukacji i rozpoczynała się w najmłodszych klasach szkoły podstawowej. 
W przypadku braku pilnych i zdecydowanych działań w postulowanych kierunkach duże różnice $\mathrm{w}$ pomiarach ducha przedsiębiorczości w Ukrainie $\mathrm{w}$ zestawieniu $\mathrm{z}$ wybranymi państwami UE oraz państwami sąsiadującymi, w tym z Polską, uzasadniają pesymistyczny scenariusz dalszego rozwoju przedsiębiorczości, co w połączeniu z pogarszającą się sytuacją demograficzną kraju, znaczącą emigracją zarobkową i słabą marką narodową może prowadzić do pogłębiania się trudności rozwojowych kraju.

\section{Literatura}

\section{References}

Ajzen, I. (1985). From intentions to actions: A theory of planned behavior. W: J. Kuhn, J. Beckman (red.), Action-control: From cognition to behavior. Heidelberg: Springer, 11-39.

Ajzen, I. (1991). The Theory of Planned Behavior. Organizational Behavior and Human Decision Processes, 50, 179-221.

Amway Global Entrepreneurship Report. (2015). Pozyskano z: https://www.amwayglobal.com/wp-content/uploads/2017/09/ager_2015_report.pdf

Amway Global Entrepreneurship Report. (2016). Pozyskano z: https://www.amwayglobal.com/wp-content/uploads/2017/09/ager_2016_publication.pdf

Amway Global Entrepreneurship Report. (2018). Pozyskano z: https://www.amwayglobal.com/wp-content/uploads/2018/05/Ager_2018_Brochure_Color.pdf

Crisp, R.J., Turner, R.N. (2015). Psychologia społeczna. Warszawa. Wydawnictwo PWN.

Grzegorzewska-Mischka, E. (2010). Współczesne uwarunkowania rozwoju przedsiębiorczości w Polsce. Warszawa: Wydawnictwo SGH.

Kavetskyy, I., Czapliński, P. (2020). Marka narodowa i jej implikacje dla procesu przedsiębiorczego (przypadek Ukrainy). Przedsiębiorczość - Edukacja, 16 (w druku).

Kurczewska, A. (2010). Problemy pomiaru intencji przedsiębiorczych. E-mentor, 4, 12-16.

Łuczka, T., Rembiasz, M. (2016). Badanie postaw przedsiębiorczych studentów - wybrane aspekty teoretyczne i empiryczne. Horyzonty Wychowania, 15, 27-47.

Moczydłowska, J., Pacewicz, I. (2007). Przedsiębiorczość. Rzeszów: WO FOSZE.

Nijkamp, P. (2003). Entrepreneurship In a Modern Network Economy. Regional Studies, 37(4), 398-400.

Pawlak, A. (2018). Determinanty intencji przedsiębiorczych młodzieży - studium porównawcze Polski i Finlandii. Poznań: Uniwersytet Ekonomiczny w Poznaniu.

Piróg, D. (2014). Uwarunkowania przedsiębiorczości absolwentów szkół wyższych: założenia teoretyczne i stan rzeczywisty. Przedsiębiorczość - Edukacja, 10, 306-315.

Rachwał, T., Wach, K. (2016). Badanie intencji przedsiębiorczych młodego pokolenia: wyniki ankietyzacji wśród studentów kierunków nieekonomicznych. Przedsiębiorczość - Edukacja, 12, 405-415.

Sadowska, M. (2017). Przedsiębiorczość indukowana a rozwój działalności gospodarczej. Białystok: Uniwersytet w Białymstoku.

Safin, K. (2002). Zarzadzanie mała firmą. Wrocław: Wydawnictwo Akademii Ekonomicznej we Wrocławiu.

Sarchynska, T. (red.) (2019). Statystychnyy shchorichnyk Czernivetskoi oblasti za 2018 rik. Chernivtsi: Derzhawna sluzhba statystyky Ukrainy.

Zbierowski, P. (2014). Determinanty intencji przedsiębiorczej studentów - wyniki badań. Horyzonty Wychowania, 13, 51-63.

Anna Czaplińska, dr, adiunkt, Uniwersytet Szczeciński, Wydział Ekonomii, Finansów i Zarządzania, Instytut Gospodarki Przestrzennej i Geografii Społeczno-Ekonomicznej, Katedra Geografii Społeczno-Ekonomicznej. Jej zainteresowania badawcze są związane z problematyką geografii społecznej i kulturowej, w tym z krajobrazem kulturowym, procesami akulturacji oraz kulturowymi uwarunkowaniami kreowania marketingu terytorialnego. 
Anna Czaplińska, PhD, assistant professor, University of Szczecin, Faculty of Economics, Finance and Management, Institute of Spatial Management and Socio-Economic Geography, Department of Socio-Economic Geography. Her research interests are related to the issues of social and cultural geography, including the cultural landscape, the processes of acculturation and the cultural determinants of creating territorial marketing.

ORCID: https://orcid.org/0000-0002-6294-5101

\section{Adres/Address:}

Uniwersytet Szczeciński

Wydział Ekonomii, Finansów i Zarządzania

Instytut Gospodarki Przestrzennej i Geografii Społeczno-Ekonomicznej

Katedra Geografii Społeczno-Ekonomicznej

ul. Mickiewicza 18

70-383 Szczecin, Polska

e-mail: anna.czaplinska@usz.edu.pl 